\title{
HILGARDIA
}

A Journal of Agricultural Science Publisbed by the California Agricultural Experiment Station

EXPERIMENTS WITH FUNGICIDES FOR USE AGAINST SCLEROTIUM ROLFSII IN SOILS

\author{
A. E. DAVEY and L. D. LEACH
}

FURTHER STUDIES ON THE INHERITANCE OF RESISTANCE TO POWDERY MILDEW OF BEANS

BJARNE DUNDAS

SNAPDRAGON RUST-RESISTANCE TRIALS

$$
\text { 1937-1938 }
$$

C. O. BLODGETT and G. A. L. MEHLQUIST

UNIVERSITY OF CALIFORNIA - BERKELEY, CALIFORNIA 


\section{FURTHER STUDIES ON THE INHERI'TANCE OF RESISTANCE TO POWDERY MILDEW OF BEANS}

BJARNE DUNDAS 



\title{
FURTHER STUDIES ON THE INHERITANCE OF RESISTANCE TO POWDERY MILDEW OF BEANS ${ }^{1,2}$
}

\author{
BJARNE DUNDAS
}

ThIS PAPER PRESENTS the results from testing various crosses of beans (Phaseolus vulgaris L.) for resistance to powdery mildew (Erysiphe polygoni D. C.). These crosses were made between the resistant varieties Striped Hopi, Lady Washington, Hungarian, Yellow, Phaseolus vulgaris 5053, Long Kidney, Pinto, and Pink, and the susceptible varieties Robust, Small White, Kotenashi, and Red Kidney, and the semiresistant variety Long Roman.

\section{METHODS}

The method of testing by inoculating detached leaflets supported on a 10 per cent sucrose solution in petri dishes as described in an earlier publication ${ }^{4}$ has also been used in this investigation. The culture of mildew was the same single-spore strain (now designated as strain 1) used in the work previously reported. The $\mathrm{F}_{1}$ and $\mathrm{F}_{2}$ plants were tested in the petri dishes, the $\mathrm{F}_{3}$ for some crosses in petri dishes and for others by field inoculation with the same strain of the mildew. Readings of the severity of mildew are given on a scale of $0-4$ for the dish tests as previously described. The field readings indicate only whether the plants are resistant or suspectible. No difference was observed among the resistant varieties, and all showed complete absence of mildew ; but differences were observed among the susceptible varieties, and between the susceptible varieties as a group, the resistant varieties as a group, and the semiresistant variety.

The crosses were all made in the greenhouse and most of the progenies grown in the field and in the greenhouses at the California Agricultural Experiment Station at Berkeley during the years 1933-1936. The $\mathrm{F}_{3}$ populations of Phaseolus vulgaris $5053 \times$ Red Kidney, Long Roman $\times$ Yellow, Long Kidney $\times$ Red Kidney, P. vulgaris $5053 \times$ Pinto, and Long Kidney $\times$ Pinto were grown in the field at the Associated Seed Growers' breeding grounds at Milpitas, California, in 1937.

\footnotetext{
${ }^{1}$ Received for publication June 26, 1939.

2 The writer is indebted to W. W. Mackie, F. N. Briggs, M. W. Gardner, and C. E. Yarwood for their assistance. The experiment herein reported was completed on the grounds of the Associated Seed Growers, Inc., while the writer was employed there as a plant breeder, and acknowledgment is due for their coöperation.

${ }^{3}$ Former Research Assistant in the Division of Agronomy; resigned June 30, 1932.

${ }^{4}$ Dundas, Bjarne. Inheritance of resistance to powdery mildew in beans. Hilgardia $10(8)$ :241-53. 1936.
} 


\section{MILDEW REACTIONS OF THE PARENTAL MATERIAL}

Table 1 gives readings of the severity of powdery mildew on the parental varieties based upon field infection and petri-dish inoculations.

The varieties Striped Hopi, Lady Washington, Hungarian, Yellow, Phaseolus vulgaris 5053, Long Kidney, and Pinto proved resistant in all dish tests. In 1932, 1933, 1935, and 1937, no mildew developed on them in the field at Berkeley, but in 1934 a small amount developed owing to the presence of a new physiologic form (form 3 ) of the mildew. When this

TABLE 1

Mildew Reaction of Varieties of Beans in Dish Tests and in the Field

\begin{tabular}{|c|c|c|c|c|c|c|c|c|c|c|}
\hline \multirow{3}{*}{ Variety } & \multirow{3}{*}{$\begin{array}{c}\text { Accession } \\
\text { No. }\end{array}$} & \multicolumn{8}{|c|}{ Number of plants with the reaction indicated } & \multirow{3}{*}{$\begin{array}{l}\text { Rat- } \\
\text { ing* }\end{array}$} \\
\hline & & \multicolumn{6}{|c|}{ Dish readings } & \multicolumn{2}{|c|}{ Field readings } & \\
\hline & & 0 & $t$ & 1 & 2 & 3 & 4 & $\begin{array}{l}\text { Resist- } \\
\text { ant }\end{array}$ & $\begin{array}{l}\text { Suscep- } \\
\text { tible }\end{array}$ & \\
\hline Striped Hopi.......... & 4927 & 15 & 0 & 0 & 0 & 0 & 0 & 19 & 0 & $\mathbf{R}$ \\
\hline Lady Washington...... & $84(213) 32$ & 15 & 0 & 0 & 0 & 0 & 0 & 20 & 0 & $\mathbf{R}$ \\
\hline Hungarian ............ & 4404 & 15 & 0 & 0 & 0 & 0 & 0 & 36 & 0 & $\mathrm{R}$ \\
\hline Yellow............. & 4429 & 15 & 0 & 0 & 0 & 0 & 0 & 78 & 0 & $\mathbf{R}$ \\
\hline Phaseolus vulgaris...... & 5053 & 40 & 0 & 0 & 0 & 0 & 0 & 40 & 0 & $\mathbf{R}$ \\
\hline Long Kidney.......... & 5045 & 15 & 0 & 0 & 0 & 0 & 0 & 40 & 0 & $\mathbf{R}$ \\
\hline Pinto.............. & 4369 & 16 & 0 & 0 & 0 & 0 & 0 & 38 & 0 & $\mathbf{R}$ \\
\hline Pink $\ldots \ldots \ldots \ldots \ldots$ & 4436 & $\ldots$ & 22 & 5 & 0 & 0 & 0 & 20 & 0 & $\mathbf{R}$ \\
\hline Robust........... & 4458 & . & 0 & 0 & 0 & 8 & 7 & 0 & 38 & $\mathbf{S}$ \\
\hline Small White.... & 4546 & . & 0 & 0 & 0 & 2 & 13 & 0 & 38 & $\mathbf{S}$ \\
\hline Kotenashi........ & 4412 & . & 0 & 0 & 0 & 0 & 15 & 0 & 40 & $\mathbf{S}$ \\
\hline Red Kidney........ & 4462 & $\cdots$ & 0 & 0 & 0 & 0 & 15 & 0 & 40 & $\mathbf{S}$ \\
\hline Long Roman.......... & 4521 & $\ldots$ & 0 & 0 & 0 & 15 & 0 & 0 & 40 & SR \\
\hline
\end{tabular}

* $\mathrm{R}=$ resistant; $\mathrm{S}=$ susceptible; $\mathrm{SR}=$ semiresistant.

new form was artificially introduced in the field plots early in 1936, the infection became rather severe, but in other places where it was not introduced, the varieties above mentioned remained free from infection.

In dish tests, the Pink variety proved to be susecptible to form 1 in the youngest stages, but it soon became resistant, with only a slight development of mildew, readings being $t$ and 1 even in rather old stages. In the field, it was resistant to form 1 but susceptible to the newly discovered form 3, as evidenced by a heavy natural infection in 1934.

The Long Roman variety was susceptible in dish tests, usually with a reading of 3 . In the field in 1932 no infection was noticed before late in the fall after most varieties were harvested. In 1933, 1935, 1936, and 1937, a small amount of infection was present; but in 1934 the variety was more severely infected, as well as in 1936, when it was inoculated with form 3 of the fungus. 
The Robust variety showed in 1932-1937 a light to medium-heavy field infection. It was highly susceptible in the dish tests, with readings of 3 and 4.

Small White, Kotenashi, and Red Kidney showed progressively heavier infection in field tests; all three varieties gave readings of 4 in all dish tests, with the exception of 2 readings of 3 for Small White.

\section{TABLE 2}

Mildew Reaction of the $\mathrm{F}_{1}$ and $\mathrm{F}_{2}$ Progenies from Crosses Between Susceptible and Resistant or Semiresistant Varieties of Beans aNd of the Parent Varieties Grown with the $\mathrm{F}_{2}$ Population

\begin{tabular}{|c|c|c|c|c|c|c|c|c|c|c|}
\hline \multirow{3}{*}{ Hybrid or variety } & \multirow{3}{*}{$\begin{array}{l}F_{1} \\
\text { dish } \\
\text { test }\end{array}$} & \multicolumn{9}{|c|}{$\mathbf{F}_{2}$} \\
\hline & & \multirow{2}{*}{ 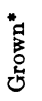 } & \multicolumn{6}{|c|}{ Number of plants with a dish test of: } & \multirow{2}{*}{$\begin{array}{c}\text { Ratio of } \\
\text { resistant : } \\
\text { susceptible }\end{array}$} & \multirow{2}{*}{$\frac{\mathrm{D}}{\mathrm{PE}}$} \\
\hline & & & $\mathbf{0}$ & $t$ & 1 & 2 & 3 & 4 & & \\
\hline \multicolumn{11}{|c|}{ Hybrids } \\
\hline Robust $\times$ Striped Hopi ... & $0, t$ & $\mathbf{F}$ & 40 & 13 & 0 & 0 & 14 & 4 & $53: 18$ & 0.10 \\
\hline Striped Hopi $\times$ Robust.... & 0 & G & 58 & 2 & 1 & 0 & 10 & 9 & $61: 19$ & 0.38 \\
\hline Lady Washington $\times$ Small & & & & & & & & & & \\
\hline White.................. & 0 & $\mathbf{F}$ & 11 & 1 & 4 & 0 & 3 & 2 & $16: 5$ & 0.19 \\
\hline Long Roman X Lady & & & & & & & & & & \\
\hline Washington............ & 0 & G & 49 & 8 & 1 & 0 & 9 & 9 & $58: 18$ & 0.39 \\
\hline Robust $\times$ Hungarian ...... & $0, t$ & $\mathbf{F}$ & 27 & 18 & 5 & 1 & 7 & 18 & $51: 25$ & 2.35 \\
\hline Long Roman $\times$ Hungarian. & 0 & $\mathbf{F}$ & 54 & 6 & 8 & 8 & 7 & 18 & $76: 25$ & 0.09 \\
\hline Hungarian $\times$ Long Roman. & 0 & G & 42 & 19 & 3 & 0 & 7 & 5 & $64: 12$ & 2.75 \\
\hline Yellow $\times$ Long Roman..... & 0 & $\mathbf{F}$ & 25 & 26 & 6 & 9 & 12 & 11 & $66: 23$ & 0.27 \\
\hline Robust $\times$ Yellow ......... & 0 & $\mathbf{G}$ & 38 & 9 & 0 & 0 & 3 & 14 & $47: 17$ & 0.43 \\
\hline Phaseolus vulgaris $5053 \times$ & & & & & & & & & & \\
\hline Red Kidney.............. & $t$ & $\mathbf{F}$ & 59 & 10 & 2 & 1 & 18 & 6 & $72: 24$ & 0.00 \\
\hline Long Kidney $\times$ Red Kidney & 1 & $\mathbf{F}$ & 19 & 27 & 27 & 21 & 21 & 7 & $94: 28$ & 0.46 \\
\hline - & $\int 1$ & $\mathbf{F}$ & 14 & 18 & 13 & 15 & 9 & 14 & $60: 23$ & 0.85 \\
\hline Robust $\times$ Pink... & $\{1$ & $\mathrm{G}$ & 0 & 40 & 24 & 16 & 0 & 22 & $80: 22$ & 0.51 \\
\hline Pink $\times$ Kotenashi $\ldots \ldots \ldots$ & 1 & G & 1 & 35 & 20 & 4 & 8 & 16 & $60: 24$ & 1.12 \\
\hline \multicolumn{11}{|c|}{ Parent varieties } \\
\hline Striped Hopi...... & .. & .. & 15 & 0 & 0 & 0 & 0 & 0 & $\ldots$ & $\ldots$ \\
\hline Lady Washington.... & . & .. & 15 & 0 & 0 & 0 & $\mathbf{0}$ & 0 & $\ldots$ & $\ldots$ \\
\hline Hungarian........... & . & .. & 15 & 0 & 0 & $\mathbf{0}$ & $\mathbf{0}$ & 0 & $\ldots$ & $\ldots$ \\
\hline Yellow.......... & . & .. & 15 & 0 & $\mathbf{0}$ & $\mathbf{0}$ & 0 & 0 & $\ldots$ & $\ldots$ \\
\hline Long Kidney............ & . & . & 9 & 0 & 0 & 0 & $\mathbf{0}$ & 0 & $\ldots$ & $\ldots$ \\
\hline Phaseolus vulgaris $5053 . . . .$. & . & .. & 5 & 1 & 0 & 0 & 0 & 0 & $\ldots$ & $\cdots$ \\
\hline Pink................... & .. & .. & 0 & 9 & 3 & 0 & 0 & 0 & $\ldots$ & $\ldots$ \\
\hline Small White........ & .. & .. & 0 & 0 & 0 & 0 & 2 & 13 & $\ldots$ & $\ldots$ \\
\hline Robust.............. & .. & .. & 0 & 0 & 0 & 0 & 13 & 14 & $\ldots$ & $\ldots$ \\
\hline Red Kidney............. & .. & .. & 0 & 0 & $\mathbf{0}$ & 0 & 6 & 9 & $\ldots$ & $\ldots$ \\
\hline Kotenashi............... & .. & . & 0 & 0 & 0 & 0 & 0 & 9 & $\ldots$ & $\ldots$ \\
\hline
\end{tabular}

- $F=$ field-grown, $G=$ greenhouse-grown. 


\section{ROBUST (S) $\times$ STRIPED HOPI (R), AND STRIPED HOPI $\times$ ROBUST}

The $F_{1}$ of Robust $(S) \times$ Striped Hopi (R) gave 1 reading of 0 and 1 of $t$, (table 2). The reading of the reciprocal cross was 0 . The $\mathrm{F}_{2}$ generations of the reciprocal crosses gave practically identical results : the Robust $x$ Striped Hopi cross had 53 resistant and 18 susceptible plants, and its

TABLE 3

Mildew Reaction of F 8 Progenies of Robust (S) $\times$ Striped Hopi (R) Beans*

\begin{tabular}{|c|c|c|c|c|c|c|c|c|c|}
\hline \multirow{2}{*}{$\begin{array}{c}\text { Dish } \\
\text { test of } \\
\mathbf{F}_{2} \\
\text { parent }\end{array}$} & \multicolumn{3}{|c|}{$F_{3}$} & \multirow{2}{*}{$\begin{array}{c}\text { Families } \\
\text { in } F_{2} \\
\text { groups }\end{array}$} & \multirow{2}{*}{$\begin{array}{c}\text { Dish } \\
\text { test of } \\
F_{2} \\
\text { parent }\end{array}$} & \multicolumn{3}{|c|}{$F_{3}$} & \multirow{2}{*}{$\begin{array}{c}\text { Families } \\
\text { in } F_{2} \\
\text { groups }\end{array}$} \\
\hline & $\begin{array}{l}\text { Resist- } \\
\text { ant } \\
\text { plants }\end{array}$ & $\begin{array}{l}\text { Suscep- } \\
\text { tible } \\
\text { plants }\end{array}$ & $\frac{D}{P E}$ & & & $\begin{array}{l}\text { Resist- } \\
\text { ant } \\
\text { plants }\end{array}$ & $\begin{array}{l}\text { Suscep- } \\
\text { tible } \\
\text { plants }\end{array}$ & $\frac{\mathrm{D}}{\mathrm{PE}}$ & \\
\hline$t$ & 54 & 15 & 0.93 & \multirow{21}{*}{ 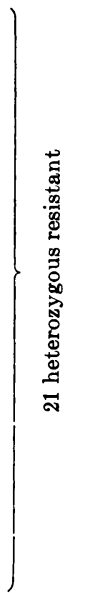 } & & & & & \multirow{12}{*}{ 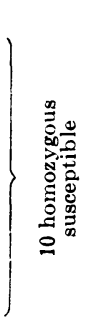 } \\
\hline$t$ & 38 & 14 & 0.47 & & 4 & 0 & 37 & .. & \\
\hline$t$ & 62 & 14 & 1.96 & & 4 & 0 & 58 & .. & \\
\hline$t$ & 72 & 20 & 1.07 & & 3 & 0 & 33 & $\therefore$ & \\
\hline$t$ & 24 & 8 & 0.00 & & 3 & 0 & 45 & & \\
\hline$t$ & 18 & 7 & 0.51 & & 3 & 0 & 76 & .. & \\
\hline$t$ & 25 & 6 & 1.07 & & 3 & 0 & 32 & $\therefore$ & \\
\hline 0 & 28 & 13 & 1.47 & & 3 & 0 & 36 & .. & \\
\hline 0 & 23 & 7 & 0.31 & & 3 & 0 & 43 & .. & \\
\hline 0 & 33 & 7 & 1.62 & & 3 & 0 & 30 & .. & \\
\hline 0 & 26 & 7 & 0.76 & & 3 & 0 & 46 & .. & \\
\hline 0 & 22 & 5 & 1.15 & & & & & & \\
\hline 0 & 75 & 21 & 1.05 & & $t$ & 37 & 0 & .. & \multirow{9}{*}{ 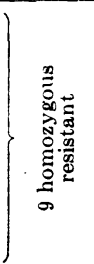 } \\
\hline 0 & 53 & 17 & 0.20 & & $t$ & 56 & 0 & & \\
\hline 0 & 30 & 8 & 0.83 & & 0 & 49 & 0 & $\therefore$ & \\
\hline 0 & 25 & 11 & 1.14 & & 0 & 40 & 0 & & \\
\hline 0 & 45 & 13 & 0.68 & & 0 & 64 & 0 & .. & \\
\hline 0 & 84 & 26 & 0.49 & & 0 & 40 & 0 & .. & \\
\hline 0 & 22 & 7 & 0.16 & & 0 & 44 & 0 & .. & \\
\hline 0 & 28 & 8 & 0.57 & & 0 & 57 & 0 & .. & \\
\hline 0 & 24 & 6 & 0.94 & & 0 & 41 & 0 & .. & \\
\hline
\end{tabular}

* Mildew reaction of parents grown at the same time: Robust, 0 resistant, 45 susceptible plants. Striped Hopi, 32 resistant, 0 susceptible plants.

reciprocal, 61 resistant and 19 susceptible. No plants had a reading of 2 and only 1 a reading of 1 ; thus there is a very clear distinction between the resistant and susceptible plants. The ratios for both crosses give a very close fit to a 3:1 ratio and indicate that the resistance in Striped Hopi is controlled by a single dominant Mendelian factor pair.

The Robust $\times$ Striped Hopi cross was carried to the $F_{3}$ generation (table 3 ). The 10 families from susceptible $\mathrm{F}_{2}$ plants with the readings of 3 and 4 contained only susceptible progeny. Of the 30 families from resistant $\mathrm{F}_{2}$ plants, 21 segregated in a $3: 1$ ratio and 9 were homozygous for resistance. The $2: 1$ ratio of segregating : homozygous families is in accordance with expectations on the basis of a one-factor difference for 
resistance between Robust and Striped Hopi and confirms the results obtained in the $\mathrm{F}_{2}$. It should be noted that the $\mathrm{F}_{2}$ dish readings of 0 and $t$ did not give any hint as to homozygosity or heterozygosity for resistance.

\section{LADY WASHINGTON (R) $\times$ SMALL WHITE (S), AND LONG ROMAN (SR) $\times$ LADY WASHINGTON (R)}

In both Lady Washington $(\mathrm{R}) \times$ Small White $(\mathrm{S})$, and Long Roman $(\mathrm{SR}) \times$ Lady Washington $(\mathrm{R})$, the $\mathrm{F}_{1}$ plants gave a 0 mildew reaction

TABLE 4

Mildew Reaction of F $F_{3}$ Progenies of Lady Washington (R) $\times$ Small WHITE (S) BEANS*

\begin{tabular}{|c|c|c|c|c|c|c|c|c|c|}
\hline \multirow{2}{*}{$\begin{array}{l}\text { Dish } \\
\text { test of } \\
F_{2} \\
\text { parent }\end{array}$} & \multicolumn{3}{|c|}{$F_{3}$} & \multirow{2}{*}{$\begin{array}{c}\text { Families } \\
\text { in } \mathrm{F}_{2} \\
\text { groups }\end{array}$} & \multirow{2}{*}{$\begin{array}{l}\text { Dish } \\
\text { test of } \\
\mathbf{F}_{2} \\
\text { parent }\end{array}$} & \multicolumn{3}{|c|}{$F_{3}$} & \multirow{2}{*}{$\begin{array}{c}\text { Families } \\
\text { in } F_{2} \\
\text { groups }\end{array}$} \\
\hline & $\begin{array}{l}\text { Resist- } \\
\text { ant } \\
\text { plants }\end{array}$ & $\begin{array}{c}\text { Suscep- } \\
\text { tible } \\
\text { plants }\end{array}$ & $\frac{\mathrm{D}}{\mathrm{PE}}$ & & & $\begin{array}{l}\text { Resist- } \\
\text { ant } \\
\text { plants }\end{array}$ & $\begin{array}{c}\text { Suscep- } \\
\text { tible } \\
\text { plants }\end{array}$ & $\frac{\mathrm{D}}{\mathrm{PE}}$ & \\
\hline $\begin{array}{l}1 \\
1 \\
1 \\
1\end{array}$ & $\begin{array}{l}41 \\
25 \\
40 \\
25\end{array}$ & $\begin{array}{l}8 \\
6 \\
8 \\
9\end{array}$ & $\begin{array}{l}2.08 \\
1.07 \\
2.02 \\
0.29\end{array}$ & \multirow{7}{*}{ 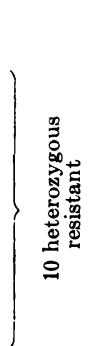 } & $\begin{array}{l}4 \\
4 \\
3 \\
3 \\
3\end{array}$ & $\begin{array}{l}0 \\
0 \\
0 \\
0 \\
0\end{array}$ & $\begin{array}{l}13 \\
45 \\
18 \\
39 \\
18\end{array}$ & $\begin{array}{l}. . \\
. . \\
. . \\
. . \\
. .\end{array}$ & 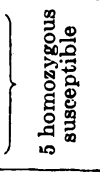 \\
\hline$t$ & 26 & 6 & $\begin{array}{l}1.21 \\
\end{array}$ & & 0 & 27 & 0 & .. & \\
\hline 0 & 25 & 5 & 1.56 & & 0 & 37 & 0 & .. & 葛 \\
\hline 0 & 20 & 5 & 0.86 & & 0 & 42 & 0 & .. & 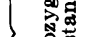 \\
\hline 0 & 36 & 5 & 2.81 & & 0 & 40 & 0 & .. & 葛 \\
\hline 0 & 42 & 7 & 2.57 & & 0 & 25 & 0 & .. & 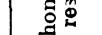 \\
\hline 0 & 25 & 7 & 0.61 & & 0 & 33 & 0 & .. & $\overrightarrow{0}$ \\
\hline
\end{tabular}

- Mildew reaction of parents grown at the same time: Lady Washington, 20 resistant, 0 susceptible plants. Small White, 0 resistant, 26 susceptible plants.

(table 2), and the distributions of the $\mathrm{F}_{2}$ readings were similar, with a distinct separation between resistant and susceptible plants by the absence of class 2. The ratios for both crosses gave a close fit to a $3: 1$ ratio, and indicate that the resistance in Lady Washington is due to a single dominant Mendelian factor.

The Lady Washington $\times$ Small White cross was carried to the $F_{3}$ generation. The $\mathrm{F}_{2}$ population of this cross was small, but every plant had a fair yield of seed and all were included in the $\mathrm{F}_{3}$ generation (see table 4). The susceptible $\mathrm{F}_{2}$ plants with readings of 3 or 4 gave only susceptible progenies. The $4 \mathrm{~F}_{2}$ plants with a reading of 1 and the 1 plant with a reading of $t$ proved to be heterozygous for resistance, while the 11 with readings of 0 were both homozygous and heterozygous. The $\mathrm{F}_{3}$ generation thus had 5 susceptible families, 10 heterozygous families segregating in a 3:1 ratio, and 6 families homozygous for resistance, which is very 
close to the expected 1:2:1 ratio, and confirms the conclusion drawn from the $\mathrm{F}_{2}$ results, that is, that the resistance in Lady Washington is due to a single dominant Mendelian factor.

\section{ROBUST (S) × HUNGARIAN (R), LONG ROMAN (SR) $\times$ HUNGARIAN (R), AND HUNGARIAN (R) $\times$ LONG ROMAN (SR)}

The $\mathrm{F}_{1}$ of Robust (S) $\times$ Hungarian (R) gave 1 reading of 0 (table 2) and 1 of $t$; Long Roman (SR) $\times$ Hungarian (R) and the reciprocal cross had 0 in both tests.

In the $\mathrm{F}_{2}$ (table 2), the Robust $\times$ Hungarian cross had 1 reading in

TABLE 5

Mildew Reaction of the $\mathrm{F}_{3}$ Progenies of Robust (S) $\times$ Hungarian (R) Beans*

\begin{tabular}{|c|c|c|c|c|c|c|c|c|c|}
\hline \multirow{2}{*}{$\begin{array}{c}\text { Dish } \\
\text { test of } \\
F_{2} \\
\text { parent }\end{array}$} & \multicolumn{3}{|c|}{$F_{3}$} & \multirow{2}{*}{$\begin{array}{c}\text { Families } \\
\text { in } F_{2} \\
\text { groups }\end{array}$} & \multirow{2}{*}{$\begin{array}{c}\text { Dish } \\
\text { test of } \\
F_{2} \\
\text { parent }\end{array}$} & \multicolumn{3}{|c|}{$F_{3}$} & \multirow{2}{*}{$\underset{\text { in } F_{2}}{\text { groups }}$} \\
\hline & $\begin{array}{l}\text { Resist- } \\
\text { ant } \\
\text { plants }\end{array}$ & $\begin{array}{l}\text { Suscep- } \\
\text { tible } \\
\text { plants }\end{array}$ & $\frac{\mathrm{D}}{\mathrm{PE}}$ & & & $\begin{array}{l}\text { Resist- } \\
\text { ant } \\
\text { plants }\end{array}$ & $\begin{array}{l}\text { Suscep- } \\
\text { tible } \\
\text { plants }\end{array}$ & $\frac{\mathrm{D}}{\mathrm{PE}}$ & \\
\hline & & & & \multirow{22}{*}{ 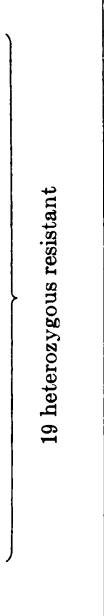 } & 4 & 0 & 30 & . & \multirow{10}{*}{ 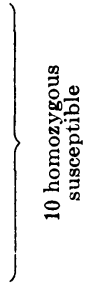 } \\
\hline 1 & 11 & 3 & 0.46 & & 4 & 0 & 24 & . & \\
\hline 1 & 36 & 11 & 0.38 & & 4 & 0 & 51 & $\ldots$ & \\
\hline$t$ & 33 & 15 & 1.49 & & 4 & 0 & 33 & $\ldots$ & \\
\hline$t$ & 32 & 13 & 0.89 & & 4 & 0 & 34 & $\ldots$ & \\
\hline$t$ & 22 & 10 & 1.21. & & 4 & 0 & 16 & $\ldots$ & \\
\hline$t$ & 12 & 7 & 1.77 & & 4 & 0 & 63 & $\ldots$ & \\
\hline$t$ & 23 & 11 & 1.47 & & 3 & 0 & 50 & $\ldots$ & \\
\hline$t$ & 18 & 4 & 1.09 & & 3 & 0 & 52 & $\ldots$ & \\
\hline$t$ & 13 & 7 & 1.53 & & 3 & 0 & 45 & 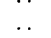 & \\
\hline \multirow{2}{*}{$t$} & 13 & 6 & 0.98 & & & & & & \multirow{12}{*}{ 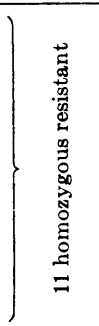 } \\
\hline & 20 & 5 & 0.86 & & 2 & 50 & 0 & .. & \\
\hline 0 & 23 & 6 & 0.80 & & 1 & 48 & 0 & $\cdots$ & \\
\hline 0 & 29 & 5 & 2.06 & & 1 & 50 & 0 & $\ldots$ & \\
\hline 0 & 19 & 6 & 0.17 & & $t$ & 31 & 0 & $\cdots$ & \\
\hline 0 & 12 & 4 & 0.00 & & $t$ & 17 & 0 & $\cdots$ & \\
\hline 0 & 71 & 22 & 0.44 & & $t$ & 51 & 0 & . & \\
\hline 0 & 18 & 4 & 1.09 & & 0 & 34 & 0 & $\ldots$ & \\
\hline 0 & 21 & 7 & 0.00 & & 0 & 34 & 0 & . & \\
\hline \multirow[t]{3}{*}{0} & 31 & 7 & 1.39 & & 0 & 14 & 0 & $\ldots$ & \\
\hline & & & & & 0 & 36 & 0 & .. & \\
\hline & & & & & 0 & 23 & 0 &. & \\
\hline
\end{tabular}

* Mildew reaction of parents grown at the same time: Robust, 0 resistant, 39 susceptible plants. Hungarian, 26 resistant, 0 susceptible plants.

the intermediate class 2, the Long Roman $\times$ Hungarian cross had 8, and the reciprocal of the latter had 0 in that class. The difference between the reciprocal crosses is attributed mainly to the difference in growing conditions, one having been grown in the greenhouse, the other in the field. A similar difference was found between a greenhouse- and field-grown 
$\mathrm{F}_{2}$ population of Long Roman $\times$ Pinto, ${ }^{5}$ the field-grown population in both cases giving more numerous intermediate readings.

The plant in the intermediate class 2 proved to be homozygous for resistance in the case of Robust $\times$ Hungarian, as will be seen from an examination of its $\mathrm{F}_{3}$ progeny (table 5). If the 8 class-2 plants in Long Roman $\times$ Hungarian are assumed to be resistant, all the data agree with the $3: 1$ ratio, which indicates that the resistance of Hungarian is due to a single dominant factor.

In the Robust $\times$ Hungarian cross (table 5 ), the 10 families from susceptible $\mathrm{F}_{2}$ plants with readings of 3 and 4 produced only susceptible $\mathrm{F}_{3}$ plants. Of the 30 families from resistant $\mathrm{F}_{2}$ plants, 19 were heterozygous for resistance, segregating in a $3: 1$ ratio, and 11 homozygous for resistance. This is close to the expected $2: 1$ ratio and confirms the $\mathrm{F}_{2}$ findings that the resistance in Hungarian is due to a single dominant Mendelian factor.

\section{ROBUST (S) $\times$ YELLOW (R) AND YELLOW (R) $\times$ LONG ROMAN (SR)}

The $\mathrm{F}_{1}$ plants in Robust $(\mathrm{S}) \times$ Yellow $(\mathrm{R})$ and Yellow $(\mathrm{R}) \times$ Long Roman (SR) (table 2) gave only readings of 0 like the resistant parent.

In the $\mathrm{F}_{2}$ population of the Robust $\times$ Yellow cross, there is a sharp distinction between the resistant and susceptible plants marked by the absence of readings in classes 1 and 2, while the Yellow $\times$ Long Roman cross, with a field-grown population, had 6 and 9 respectively in classes 1 and 2. This difference is not entirely due to the fact that one population was grown in the field and the other in the greenhouse. The Long Roman in its crosses tends to level out the sharp difference found between resistant and susceptible plants in other crosses. The Long Roman variety itself has a certain resistance in the field, while in the dishes it is susceptible, usually giving a reading of 3 . If class 2 is counted with the resistants, as previously, both the Yellow crosses have a very close fit to a 3:1 ratio, and Yellow must, like the preceding resistant varieties, owe its resistance to a single dominant Mendelian factor.

$\mathrm{An}_{3}$ population of Yellow $\times$ Long Roman was grown from seed from 10 susceptible and 33 resistant $\mathrm{F}_{2}$ plants, including 4 with a mildew reading of 2 (table 6 ). The $F_{2}$ plants were the progenies from one $F_{1}$ plant. The populations of the 10 susceptible $\mathrm{F}_{3}$ families ranged from 14 to 27 , the susceptible plants usually giving less seed because of mildew attack in the field. The populations of the 33 resistant $\mathrm{F}_{3}$ families ranged from 18 to 50 with only 5 families below 27 , the maximum population of the susceptible families.

\footnotetext{
${ }^{5}$ Dundas, Bjarne. Inheritance of resistance to powdery mildew in beans. Hilgardia
} $10(8): 250.1936$. 
TABLE 6

Mildew Reaction of the $\mathrm{F}_{3}$ Progenies of Yellow $(\mathrm{R}) \times$ Long ROMAN (SR) BEANS*

\begin{tabular}{|c|c|c|c|c|c|c|c|c|c|}
\hline \multirow{3}{*}{$\begin{array}{l}\text { Dish } \\
\text { test of } F_{2} \\
\text { parent }\end{array}$} & \multicolumn{8}{|c|}{$\mathbf{F}_{\mathbf{8}}$} & \multirow{3}{*}{$\begin{array}{c}\text { Families in } \\
F_{2} \text { groups }\end{array}$} \\
\hline & \multicolumn{6}{|c|}{ Number of plants with a dish test of: } & \multirow{2}{*}{$\begin{array}{l}\text { Ratio of } \\
\text { resistant : } \\
\text { susceptible }\end{array}$} & \multirow{2}{*}{$\frac{\mathrm{D}}{\mathrm{PE}}$} & \\
\hline & 0 & $t$ & 1 & 2 & 3 & 4 & & & \\
\hline 4 & $\mathbf{0}$ & 0 & 0 & $\mathbf{0}$ & 13 & 14 & $0: 27$ & $\cdots$ & \\
\hline 4 & $\mathbf{0}$ & 0 & 0 & $\mathbf{0}$ & 7 & 11 & $0: 18$ & $\ldots$ & \\
\hline 4 & 0 & 0 & 0 & $\mathbf{0}$ & 6 & 8 & $0: 14$ & $\ldots$ & \\
\hline 4 & 0 & 0 & $\mathbf{0}$ & $\mathbf{0}$ & 7 & 12 & $0: 19$ & $\ldots$ & \\
\hline 3 & 0 & 0 & 0 & 0 & 12 & 15 & $0: 27$ & $\ldots$ & 10 homozygous \\
\hline 3 & 0 & 0 & 0 & 0 & 12 & 10 & $0: 22$ & $\ldots$ & susceptible \\
\hline 3 & 0 & 0 & 0 & 0 & 10 & 10 & $0: 20$ & $\ldots$ & \\
\hline 3 & 0 & 0 & 0 & 0 & 1 & 17 & $0: 18$ & $\ldots$ & \\
\hline 3 & 0 & 0 & 0 & 0 & 4 & 20 & $0: 24$ & $\ldots$ & \\
\hline 3 & 0 & 0 & 0 & 0 & 10 & 5 & $0: 15$ & $\ldots$ & \\
\hline 2 & 3 & 18 & 4 & 0 & 8 & 0 & $25: 8$ & 0.15 & ) \\
\hline 2 & 16 & 10 & 1 & 1 & 5 & 1 & $28: 6$ & 1.47 & \\
\hline 2 & 5 & 13 & 3 & 1 & 8 & 0 & $22: 8$ & 0.31 & \\
\hline 2 & 18 & 12 & 1 & 0 & 7 & 3 & $31: 10$ & 0.13 & \\
\hline 1 & 6 & 8 & 0 & 0 & 3 & 2 & $14: 5$ & 0.59 & \\
\hline 1 & 20 & 9 & 2 & 0 & 5 & 5 & $31: 10$ & 0.13 & \\
\hline 1 & 12 & 23 & 3 & 0 & 4 & 4 & $38: 8$ & 1.26 & \\
\hline 1 & 7 & 18 & 2 & 1 & 6 & 5 & $28: 11$ & 0.69 & \\
\hline$t$ & 10 & 12 & 1 & 0 & 4 & 2 & $23: 6$ & 0.80 & \\
\hline$t$ & 16 & 14 & 0 & 0 & 5 & 3 & $30: 8$ & 0.83 & 21 \\
\hline$t$ & 5 & 9 & 0 & 0 & 4 & 0 & $14: 4$ & 0.40 & heterozygous \\
\hline$t$ & 14 & 20 & 3 & 0 & 8 & 5 & $37: 13$ & 0.24 & resistant \\
\hline$t$ & 12 & 14 & 0 & 0 & 6 & 4 & $26: 10$ & 0.57 & \\
\hline$t$ & 13 & 15 & 1 & 1 & 9 & 0 & $30: 9$ & 0.41 & \\
\hline$t$ & 8 & 21 & 1 & 0 & 7 & 1 & $30: 8$ & 0.83 & \\
\hline$t$ & 5 & 14 & 0 & 0 & 6 & 0 & $19: 6$ & 0.17 & \\
\hline 0 & 12 & 19 & 0 & 0 & 9 & 0 & $31: 9$ & 0.54 & \\
\hline 0 & 6 & 20 & 3 & 0 & 9 & 2 & $29: 11$ & 0.54 & \\
\hline 0 & 20 & 14 & 0 & 0 & 10 & 0 & $34: 10$ & 0.52 & \\
\hline 0 & 7 & 10 & 1 & 0 & 5 & 1 & $18: 6$ & 0.00 & \\
\hline 0 & 11 & 14 & 1 & 0 & 5 & 5 & $26: 10$ & 0.57 & \\
\hline 1 & 31 & 8 & 1 & 0 & 0 & 0 & $40: 0$ & $\ldots$ & ) \\
\hline 1 & 25 & 10 & 4 & $\mathbf{0}$ & 0 & 0 & $39: 0$ & $\ldots$ & \\
\hline$t$ & 10 & 22 & 2 & 0 & 0 & 0 & $34: 0$ & $\ldots$ & \\
\hline$t$ & 18 & 15 & 1 & 0 & 0 & 0 & $34: 0$ & $\ldots$ & \\
\hline$t$ & 20 & 7 & 2 & 0 & 0 & 0 & $29: 0$ & $\ldots$ & \\
\hline$t$ & 11 & 10 & 2 & 0 & 0 & 0 & $23: 0$ & $\ldots$ & 12 homozygous \\
\hline$t$ & 23 & 6 & 0 & 0 & 0 & 0 & $29: 0$ & $\ldots$ & resistant \\
\hline 0 & 28 & 4 & 3 & 0 & 0 & 0 & $35: 0$ & $\ldots$ & \\
\hline 0 & 27 & 13 & 1 & 0 & 0 & 0 & $41: 0$ & $\ldots$ & \\
\hline 0 & 18 & 10 & 0 & 0 & 0 & 0 & $28: 0$ & $\ldots$ & \\
\hline 0 & 28 & 17 & 0 & 0 & 0 & 0 & $45: 0$ & $\ldots$ & \\
\hline 0 & 31 & 7 & 0 & 0 & 0 & 0 & $38: 0$ & $\ldots$ & \\
\hline
\end{tabular}

- Mildew reaction of parents grown at the same time: Yellow, all 15 plants grown, dish-test reading of 0 . Long Roman, all 15 plants grown, dish-test reading of 3. 
Of the 33 resistant $\mathrm{F}_{2}$ plants (readings $0, t, 1$, and 2 ), 12 proved to be homozygous and 21 heterozygous for resistance, which is close to the $1: 2$ ratio expected from a random sample. The 21 heterozygous $F_{2}$ plants segregated in $\mathrm{F}_{3}$ in accordance with the single-factor hypothesis. The

\section{TABLE 7}

Mildew Reaction of the $F_{3}$ Progenies of Phaseolus Vulgaris $5053(\mathrm{R}) \times$ RED KIDNEY (S) BEANS*

\begin{tabular}{|c|c|c|c|c|c|c|c|c|}
\hline \multirow{3}{*}{$\begin{array}{c}\text { Dish } \\
\text { test of } F_{2} \\
\text { parent }\end{array}$} & \multicolumn{7}{|c|}{$\mathbf{F}_{\mathbf{3}}$} & \multirow{3}{*}{$\underset{\mathbf{F}_{2} \text { groups }}{\text { Families in }}$} \\
\hline & \multicolumn{5}{|c|}{ Number of plants with a dish test of: } & \multirow{2}{*}{$\begin{array}{c}\text { Ratio of } \\
\text { resistant: } \\
\text { susceptible }\end{array}$} & \multirow{2}{*}{$\frac{\mathrm{D}}{\mathrm{PE}}$} & \\
\hline & $\mathbf{0}$ & $t$ & 1 & 2 & 3 and 4 & & & \\
\hline 3 & 0 & 0 & 0 & 0 & 23 & $0: 23$ & $\ldots$ & \\
\hline 3 & 0 & $\mathbf{0}$ & 0 & 0 & 28 & $0: 28$ & $\ldots$ & \\
\hline 3 & 0 & 0 & 0 & 0 & 19 & $0: 19$ & $\ldots$ & \\
\hline 3 & $\mathbf{0}$ & $\mathbf{0}$ & 0 & 0 & 23 & $0: 23$ & $\ldots$ & 9 homozygous \\
\hline 3 & 0 & 0 & 0 & 0 & 26 & $0: 26$ & $\ldots$ & susceptible \\
\hline 3 & 0 & 0 & 0 & 0 & 25 & $0: 25$ & $\ldots$ & \\
\hline 3 & $\mathbf{0}$ & 0 & 0 & 0 & 15 & $0: 15$ & $\ldots$ & \\
\hline 3 & 0 & 0 & 0 & 0 & 18 & $0: 18$ & $\ldots$ & \\
\hline 3 & 0 & 0 & 0 & 0 & 15 & $0: 15$ & $\ldots$ & \\
\hline$t$ & 15 & 0 & 0 & 0 & 4 & $15: 4$ & 0.59 & 1 \\
\hline$t$ & 21 & 0 & 0 & 0 & 5 & $21: 5$ & 1.00 & \\
\hline$t$ & 20 & 3 & 0 & 0 & 4 & $23: 4$ & 1.81 & \\
\hline$t$ & 27 & 3 & 0 & 0 & 11 & $30: 11$ & 0.40 & \\
\hline 0 & 12 & 3 & 1 & 0 & 6 & $16: 6$ & 0.36 & \\
\hline 0 & 12 & 3 & 0 & 0 & 5 & $15: 5$ & 0.00 & \\
\hline 0 & 10 & 5 & 2 & 0 & 4 & $17: 4$ & 0.93 & \\
\hline 0 & 14 & 2 & 0 & 0 & 4 & $16: 4$ & 0.76 & 17 \\
\hline 0 & 24 & 0 & 0 & 0 & 8 & $24: 8$ & 0.00 & heterozygous \\
\hline 0 & 20 & 0 & 0 & 0 & 6 & $20: 6$ & 0.34 & resistant \\
\hline 0 & 16 & $\mathbf{0}$ & $\mathbf{0}$ & 0 & 4 & $16: 4$ & 0.76 & \\
\hline 0 & 9 & 3 & 0 & 0 & 7 & $12: 7$ & 1.31 & \\
\hline $\mathbf{0}$ & 14 & 0 & 0 & 0 & 6 & $14: 6$ & 0.76 & \\
\hline 0 & 20 & 4 & 2 & 1 & 7 & $27: 7$ & 0.88 & \\
\hline 0 & 24 & 5 & 0 & 0 & 5 & $29: 5$ & 2.06 & \\
\hline 0 & 31 & 2 & 1 & 0 & 7 & $34: 7$ & 1.74 & \\
\hline 0 & 20 & 6 & 0 & 1 & 9 & $27: 9$ & 0.00 & \\
\hline 0 & 29 & 0 & 0 & 0 & 0 & $29: 0$ & $\ldots$ & ) \\
\hline 0 & 16 & 2 & 1 & 1 & 0 & $20: 0$ & $\ldots$ & \\
\hline 0 & 26 & 0 & 0 & 0 & 0 & $26: 0$ & $\cdots$ & \\
\hline 0 & 21 & 0 & 0 & 0 & 0 & $21: 0$ & $\ldots$ & 8 homozygous \\
\hline 0 & 24 & 0 & 0 & 0 & 0 & $24: 0$ & $\ldots$ & resistant \\
\hline 0 & 32 & $\mathbf{0}$ & 0 & 0 & 0 & $32: 0$ & $\ldots$ & \\
\hline $\mathbf{0}$ & 20 & 0 & 0 & 0 & 0 & $20: 0$ & $\ldots$ & \\
\hline 0 & 20 & 0 & 0 & 0 & 0 & $20: 0$ & $\ldots$ & $\int$ \\
\hline
\end{tabular}

- Mildew reaction of parents grown at the same time: Phaseolus vulgaris 5053, all 26 plants grown, dishtest reading of 0 . Red Kidney, all 20 plants grown, dish-test reading of 3 .

susceptible $\mathrm{F}_{2}$ plants (readings 3 and 4 ) gave only susceptible progeny. It should be noted that the tested $\mathrm{F}_{2}$ plants with a reading of 2 were all heterozygous for resistance, while readings $1, t$, and 0 did not give any indication of a homozygous or heterozygous condition. 


\section{PHASEOLUS VULGARIS $5053(\mathrm{R}) \times$ RED KIDNEY (S)}

The $\mathrm{F}_{1}$ plant of the Phaseolus vulgaris $5053(\mathrm{R}) \times$ Red Kidney $(\mathrm{S})$ cross gave a reading of $t$ in the dish test, which indicates that the resistance is dominant (table 2). The $\mathrm{F}_{2}$ generation all came from one plant and consisted of 72 resistant and 24 susceptible plants. This is a perfect $3: 1$ ratio and indicates a single dominant factor for resistance to mildew in $P$. vulgaris 5053. All the plants that gave enough seed were used for the $\mathrm{F}_{3}$ generation (table 7 ). The 2 plants with a reading of 1 , the 1 with a reading of 2 , and the 6 with a reading of 4 had not enough seed for an $F_{3}$ population. The populations of the $\mathrm{F}_{3}$ families ranged between 15 and 41 and were dish-tested as indicated in table 7 . No distinction was made between the susceptible readings 3 and 4, which are recorded together under one heading.

Of the 25 resistant $F_{2}$ plants, 8 were homozygous and 17 heterozygous for resistance.This is close to the 1:2 ratio expected on the basis of a single factor for resistance. The 17 heterozygous $\mathrm{F}_{2}$ plants segregated in $\mathrm{F}_{3}$ according to expectations. All $\mathrm{F}_{2}$ plants with a reading of $t$ were heterozygous for resistance while those with a reading of 0 were both homozygous and heterozygous for resistance.

\section{LONG KIDNEY (R) $\times$ RED KIDNEY (S)}

The $\mathrm{F}_{1}$ of Long Kidney (R) $\times$ Red Kidney $(\mathrm{S})$ gave a reading of 1 in the dish test (table 2), which indicates the dominance of the resistance in Long Kidney.

The $\mathrm{F}_{2}$ population of this cross has a proportionately much larger number of plants with an intermediate reading than did that of any other cross ; as shown in table 2 , out of a total population of 122 , there are 27 with a reading of 1 and 21 with a reading of 2 . From 7 of the $F_{2}$ plants with readings of 2 there were grown $F_{3}$ populations (table 8 ), all of which segregated, which shows that these plants were heterozygous for resistance. Assuming that the remainder of this class (reading of 2) of $\mathrm{F}_{2}$ plants are also resistant, there are 94 resistant and 28 susceptible plants, which agrees fairly closely with the $3: 1$ ratio and indicates that the resistance of Long Kidney is due to a single dominant factor.

Only 25 plants had sufficent seed for $\mathrm{F}_{3}$ populations. These were all planted and gave $\mathrm{F}_{3}$ families with populations ranging from 20-49 (table 8 ). The 4 families from susceptible $F_{2}$ plants gave all susceptible plants. Of the 21 families from the resistant plants, 14 were heterozygous for resistance, segregating in a $3: 1$ ratio, and 7 homozygous for resistance. This is a perfect $2: 1$ ratio and confirms the $\mathrm{F}_{2}$ findings that the resistance in the Long Kidney is due to a single dominant factor. It should be 
noted that all the progeny-tested $F_{2}$ plants with readings of 2 were heterozygous for resistance while those with readings of $0, t$, and 1 were both homozygous and heterozygous.

\section{PINK $(R) \times$ KOTENASHI $(S)$ AND ROBUST $(S) \times$ PINK $(R)$}

The $F_{1}$ in Pink $(R) \times$ Kotenashi $(S)$ and Robust $(S) \times$ Pink $(R)$ all gave a reading of 1 when leaves were taken from older plants (table 2 ). In the early seedling stage the $\mathrm{F}_{1}$ plants gave a susceptible reaction of 3

TABLE 8

Mildew Reaction of the $\mathrm{F}_{3}$ Progenies of Long Kidney

$(\mathrm{R}) \times \operatorname{RED}$ KIDNEY (S) BeANS*

\begin{tabular}{|c|c|c|c|c|c|c|c|c|c|}
\hline \multirow{2}{*}{$\begin{array}{c}\text { Dish } \\
\text { test of } \\
\mathrm{F}_{2} \\
\text { parent }\end{array}$} & \multicolumn{3}{|c|}{$\mathbf{F}_{3}$} & \multirow{2}{*}{$\begin{array}{c}\text { Families } \\
\text { in } F_{2} \\
\text { groups }\end{array}$} & \multirow{2}{*}{$\begin{array}{c}\text { Dish } \\
\text { test of } \\
F_{2} \\
\text { parent }\end{array}$} & \multicolumn{3}{|c|}{$\mathbf{F}_{3}$} & \multirow{2}{*}{$\begin{array}{c}\text { Families } \\
\text { in } \mathrm{F}_{2} \\
\text { groups }\end{array}$} \\
\hline & $\begin{array}{l}\text { Resist- } \\
\text { ant } \\
\text { plants }\end{array}$ & $\begin{array}{c}\text { Suscep- } \\
\text { tible } \\
\text { plants }\end{array}$ & $\frac{\mathrm{D}}{\mathrm{PE}}$ & & & $\begin{array}{l}\text { Resist- } \\
\text { ant } \\
\text { plants }\end{array}$ & $\begin{array}{l}\text { Suscep- } \\
\text { tible } \\
\text { plants }\end{array}$ & $\frac{\mathrm{D}}{\mathrm{PE}}$ & \\
\hline 2 & 18 & 6 & 0.00 & \multirow{14}{*}{ 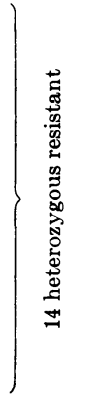 } & & & & & \multirow{6}{*}{ 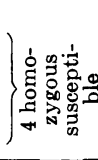 } \\
\hline 2 & 18 & 5 & 0.53 & & 4 & 0 & 24 & .. & \\
\hline 2 & 36 & 13 & 0.37 & & 4 & 0 & 24 & $\ldots$ & \\
\hline 2 & 23 & 7 & 1.25 & & 4 & 0 & 20 & $\ldots$ & \\
\hline 2 & 23 & 8 & 0.15 & & 3 & 0 & 26 & $\ldots$ & \\
\hline 2 & 21 & 8 & 0.48 & & & & & & \\
\hline 2 & 18 & 6 & 0.00 & & 1 & 28 & 0 & .. & \multirow{8}{*}{ 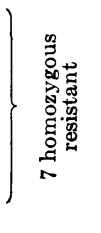 } \\
\hline 1 & 26 & 9 & 0.14 & & 1 & 23 & 0 & .. & \\
\hline 1 & 31 & 9 & 0.54 & & $t$ & 26 & 0 & $\ldots$ & \\
\hline 1 & 16 & 5 & 0.19 & & $t$ & 30 & 0 & .. & \\
\hline$t$ & 23 & 7 & 0.31 & & 0 & 30 & 0 & $\ldots$ & \\
\hline$t$ & 25 & 9 & 0.26 & & 0 & 31 & 0 & .. & \\
\hline 0 & 21 & 7 & 0.00 & & 0 & 20 & 0 & $\ldots$ & \\
\hline 0 & 22 & 6 & 0.65 & & & & & & \\
\hline
\end{tabular}

* Mildew reaction of parents grown at the same time: Red Kidney, 0 resistant, 20 susceptible. Long Kidney, 20 resistant, 0 susceptible.

or 4 . This agrees with earlier findings ${ }^{6}$ that the Pink variety was susceptible in the early seedling stage but resistant later.

The $\mathrm{F}_{2}$ generation of Pink $\times$ Kotenashi was grown in the greenhouse. In an early test, most plants appeared rather susceptible. New tests were made when the plants were approximately one and two months old, and in the last test three leaflets from each plant were used. The average readings from the old leaflets of the two last tests gave 60 resistant and 24 susceptible plants, not far from a ratio of $3: 1$ as in the previous crosses. This indicates that the resistance in Pink is also due to a single dominant factor pair.

An $\mathrm{F}_{2}$ of Robust $\times$ Pink was also grown in the greenhouse. Five tests were made of this cross, the first when the plants were about 9-14 days old, the following 16, 24, 32, and 45 days later. The first test showed many

- Dundas, Bjarne. Inheritance of resistance to powdery mildew in beans. Hilgardia $10(8): 246.1936$. 
TABLE 9

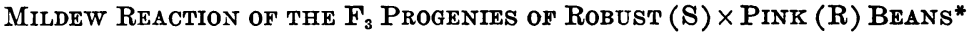

\begin{tabular}{|c|c|c|c|c|c|c|c|c|c|}
\hline \multirow{2}{*}{$\begin{array}{c}\text { Dish } \\
\text { test of } F_{2} \\
\text { parent }\end{array}$} & \multicolumn{6}{|c|}{ Number of plants with a dish test of: } & \multirow{2}{*}{$\begin{array}{l}\text { Ratio of } \\
\text { resistant : } \\
\text { susceptible }\end{array}$} & \multirow{2}{*}{$\frac{\mathrm{D}}{\mathrm{PE}}$} & \multirow{2}{*}{$\underset{\mathbf{F}_{2} \text { groups }}{\text { Families in }}$} \\
\hline & $\mathbf{0}$ & $t$ & 1 & 2 & 3 & 4 & & & \\
\hline 4 & 0 & $\mathbf{0}$ & 0 & 0 & 25 & 8 & $0: 33$ & $\ldots$ & \\
\hline 4 & $\mathbf{0}$ & $\mathbf{0}$ & 0 & 0 & 30 & 3 & $0: 33$ & $\ldots$ & \\
\hline 4 & $\mathbf{0}$ & 0 & 0 & $\mathbf{0}$ & 28 & 0 & $0: 28$ & $\ldots$ & \\
\hline 4 & 0 & 0 & $\mathbf{0}$ & $\mathbf{0}$ & 18 & 15 & $0: 33$ & $\ldots$ & \\
\hline 4 & $\mathbf{0}$ & 0 & 0 & $\mathbf{0}$ & 15 & 6 & $0: 21$ & $\ldots$ & \\
\hline 4 & 0 & 0 & 0 & 0 & 12 & 22 & $0: 34$ & $\ldots$ & 13 \\
\hline 4 & 0 & 0 & 0 & 0 & 17 & 15 & $0: 32$ & $\ldots$ & homozygous \\
\hline 4 & 0 & 0 & 0 & 0 & 31 & 11 & $0: 42$ & $\ldots$ & susceptible \\
\hline 4 & 0 & 0 & 0 & 0 & 10 & 15 & $0: 25$ & $\ldots$ & \\
\hline 4 & 0 & 0 & 0 & 0 & 29 & 12 & $0: 41$ & $\cdots$ & \\
\hline 3 & 0 & 0 & 0 & 0 & 16 & 14 & $0: 30$ & $\ldots$ & \\
\hline 3 & 0 & 0 & 0 & 0 & 22 & 10 & $0: 32$ & $\ldots$ & \\
\hline 3 & 0 & 0 & 0 & 0 & 33 & 0 & $0: 33$ & $\ldots$ & \\
\hline 2 & 0 & 6 & 14 & 1 & 0 & 5 & $21: 5$ & 1.00 & \\
\hline 2 & 2 & 20 & 20 & 1 & 10 & 3 & $43: 13$ & 0.50 & \\
\hline 2 & 0 & 9 & 11 & 4 & 5 & 3 & $24: 8$ & 0.00 & \\
\hline 2 & 1 & 9 & 13 & 0 & 4 & 4 & $23: 8$ & 0.15 & \\
\hline 2 & 4 & 14 & 13 & 0 & 7 & 2 & $31: 9$ & 0.54 & \\
\hline 2 & 0 & 12 & 14 & 0 & 4 & 2 & $26: 6$ & 1.23 & \\
\hline 2 & 3 & 14 & 6 & 0 & 8 & 5 & $23: 13$ & 0.76 & \\
\hline 2 & 0 & 8 & 13 & 2 & 3 & 3 & $23: 6$ & 0.80 & \\
\hline 1 & 0 & 16 & 12 & 2 & 8 & 3 & $30: 11$ & 0.40 & \\
\hline 1 & 0 & 9 & 15 & 3 & 5 & 5 & $27: 10$ & 0.42 & \\
\hline 1 & 1 & 16 & 17 & 0 & 3 & 3 & $34: 6$ & 2.16 & 24 \\
\hline 1 & 0 & 14 & 15 & 0 & 3 & 8 & $29: 11$ & 0.54 & heterozygous \\
\hline 1 & 0 & 20 & 7 & 0 & 8 & 1 & $27: 9$ & 0.00 & resistant \\
\hline 1 & 3 & 16 & 8 & 0 & 5 & 5 & $27: 10$ & 0.42 & \\
\hline 1 & 5 & 13 & 10 & 1 & 5 & 5 & $29: 10$ & 0.14 & \\
\hline$t$ & 0 & 12 & 13 & 2 & 5 & 6 & $27: 11$ & 0.83 & \\
\hline$t$ & 2 & 12 & 9 & 0 & 4 & 5 & $23: 9$ & 0.61 & \\
\hline$t$ & 0 & 8 & 9 & 1 & 5 & 2 & $18: 7$ & 0.51 & \\
\hline$t$ & 0 & 16 & 3 & 0 & 3 & 4 & $19: 7$ & 0.34 & \\
\hline$t$ & 10 & 9 & 8 & 0 & 6 & 4 & $27: 10$ & 0.42 & \\
\hline$t$ & 0 & 7 & 16 & 2 & 5 & 2 & $25: 7$ & 0.61 & \\
\hline 0 & 3 & 8 & 10 & 0 & 2 & 3 & $21: 5$ & 1.00 & \\
\hline 0 & 7 & 10 & 3 & 0 & 5 & 2 & $20: 7$ & 0.16 & \\
\hline 0 & 0 & 9 & 9 & 0 & 4 & 1 & $18: 5$ & 0.54 & \\
\hline 1 & 0 & 17 & 15 & 0 & 0 & 0 & $32: 0$ & $\ldots$ & \\
\hline$t$ & 4 & 28 & 10 & 0 & 0 & 0 & $42: 0$ & $\ldots$ & \\
\hline$t$ & 2 & 15 & 6 & 0 & 0 & 0 & $23: 0$ & $\ldots$ & \\
\hline$t$ & 3 & 18 & 5 & 0 & 0 & 0 & $26: 0$ & $\ldots$ & \\
\hline$t$ & 8 & 9 & 19 & 2 & 0 & 0 & $38: 0$ & $\ldots$ & \\
\hline$t$ & 3 & 12 & 8 & 0 & 0 & 0 & $23: 0$ & $\ldots$ & 12 homozygous \\
\hline 0 & 8 & 12 & 2 & 0 & 0 & 0 & $22: 0$ & $\ldots$ & resistant \\
\hline 0 & 5 & 16 & 12 & 0 & 0 & 0 & $33: 0$ & $\ldots$ & \\
\hline 0 & 0 & 23 & 10 & 0 & 0 & 0 & $33: 0$ & $\ldots$ & \\
\hline 0 & 2 & 22 & 15 & 0 & 0 & 0 & $39: 0$ & $\ldots$ & \\
\hline 0 & 3 & 12 & 12 & 0 & 0 & 0 & $27: 0$ & $\ldots$ & \\
\hline 0 & 3 & 18 & 8 & 0 & 0 & 0 & $29: 0$ & $\ldots$ & \\
\hline
\end{tabular}

* Mildew reaction of parents grown at the same time: Robust, 10 plants with a dish-test reading of 3 , 5 with a reading of 4 . Pink, 13 plants with a dish-test reading of 0,2 with a reading of $t$. 
plants to be susceptible which later became resistant. The results given in table 2 are based on the average of the later tests made on fully developed leaflets when the plants had become resistant. The fully developed leaflets usually show more resistance than the younger ones. The ratio 80 resistant : 22 susceptible, is fairly close $\left(\frac{\mathrm{D}}{\mathrm{PE}}=0.51\right)$ to a $3: 1$ ratio and confirms the finding of the Pink $\times$ Kotenashi cross.

Another $\mathrm{F}_{2}$ population of Robust $\times$ Pink was grown in the field for the purpose of obtaining seed for an $\mathrm{F}_{3}$ population. Only a single dish test was made of this when the plants had attained resistance, except for doubtful cases, which were retested. The result is seen from table 2 to be 60 resistant : 23 susceptible, close to the ratio obtained in the greenhousegrown cross. The $\mathrm{F}_{3}$ grown from this cross (table 9 ) was taken from 13 of the field-grown susceptible $\mathrm{F}_{2}$ plants with readings of 3 and 4 and 36 of the resistant plants with readings of $0-2$. The families from the 13 susceptible plants all gave susceptible progenies, while, of those from the resistant plants, 24 segregated in a ratio of 3 resistant: 1 susceptible and 12 were homozygous for resistance. The $2: 1$ ratio of segregating : homozygous resistant families is in accordance with expectations on the basis of a one-factor difference for resistance between Robust and Pink and confirms the results obtained in the $\mathrm{F}_{2}$. It should be noted that all the $\mathrm{F}_{2}$ plants with readings of 2 and 1 (except 1 with a reading of 1 ) proved to be heterozygous for resistance, whereas the readings of 0 and $t$ did not give any indication of homozygosity or heterozygosity of the plants.

\section{CROSSES BETWEEN RESISTANT VARIETIES}

Crosses between resistant varieties were made as follows and carried to the $\mathrm{F}_{3}$ generation : Lady Washington $\times$ Pinto, Hungarian $\times$ Pinto, Yellow $\times$ Pinto, Phaseolus vulgaris $5053 \times$ Pinto, Pinto $\times$ Striped Hopi, Long Kidney $\times$ Pinto, and Pinto $\times$ Pink. Crosses of Yellow $\times$ Hungarian and Yellow $\times P$. vulgaris 5053 were carried to $\mathrm{F}_{2}$. These were all similar in reaction to mildew and will be treated together. The $\mathrm{F}_{1}$ plants gave only readings of 0 , except the Yellow $\times$ Pinto cross which gave $t$ for 1 of the 2 readings (see table 10).

The $\mathrm{F}_{\mathbf{2}}$ plants of all crosses (table 10) reacted much like the parents. The Lady Washington $\times$ Pinto cross had only 0 readings, as did the Yellow $\times$ Pinto, the Yellow $\times$ Phaseolus vulgaris 5053, P. vulgaris $5053 \times$ Pinto, Pinto $\times$ Striped Hopi, and Long Kidney $\times$ Pinto crosses. The Hungarian $\times$ Pinto cross had 99 readings of 0 and 1 of $t$. The parents of this cross had readings of 0 , but if a larger number of plants had been tested, the chances are that a reading of $t$ might have occurred. The Yellow $x$ Hungarian cross gave 82 readings of 0 and 9 of $t$. This population was 
grown in the field, and, as observed before, the field-grown plants often show some higher readings than those grown in the greenhouse. Two populations of Pinto $\times$ Pink crosses gave the same proportion of the same readings; combined they gave 82 readings of 0,43 of $t, 12$ of 1 , and 8 of 2 . These numerous intermediate readings, like those obtained with the Robust $\times$ Pink cross, indicate the presence of modifying factors.

The results of crosses with susceptible varieties (tables 2-9), pre-

\section{TABLE 10}

Mildew Reaction of the $F_{1}, F_{2}$, and $F_{3}$ Progenies of Certain Mildew-Resistant Bean Varieties

\begin{tabular}{|c|c|c|c|c|c|c|c|c|c|c|c|c|}
\hline \multirow{3}{*}{$\begin{array}{c}\text { Hybrid and } \\
\text { variety }\end{array}$} & \multirow{3}{*}{$\begin{aligned} F_{1} \\
\text { dish } \\
\text { test }\end{aligned}$} & \multicolumn{7}{|c|}{$F_{2}$ and parents } & \multicolumn{4}{|c|}{$F_{3}$} \\
\hline & & \multirow{2}{*}{ 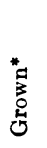 } & \multicolumn{6}{|c|}{ Number of plants with a dish test of: } & \multirow{2}{*}{ 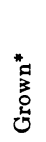 } & \multicolumn{2}{|c|}{$\begin{array}{l}\text { Number of } \\
\text { families }\end{array}$} & \multirow{2}{*}{$\begin{array}{c}\text { Numer- } \\
\text { ical } \\
\text { range } \\
\text { of } \\
\text { popu- } \\
\text { lations }\end{array}$} \\
\hline & & & 0 & $t$ & 1 & 2 & 3 & 4 & & Tested & $\underset{\text { ant }}{\text { Resist- }}$ & \\
\hline $\begin{array}{r}\text { Lady Washington } \\
\times \text { Pinto........ }\end{array}$ & 0 & G & 93 & 0 & 0 & 0 & 0 & 0 & $\mathbf{F}$ & 48 & 48 & $22-84$ \\
\hline $\begin{array}{l}\text { Hungarian } \times \\
\text { Pinto............... }\end{array}$ & . & G & 99 & 1 & 0 & 0 & 0 & 0 & $\mathbf{F}$ & 48 & 48 & $17-55$ \\
\hline $\begin{array}{l}\text { Yellow } \times \text { Pinto. } \\
\text { Yellow } \times\end{array}$ & $0 \& t$ & G & 97 & 0 & 0 & 0 & 0 & 0 & F & 45 & 45 & $17-58$ \\
\hline $\begin{array}{l}\text { Hungarian ...... } \\
\text { Yellow } \times \text { Phaseo- }\end{array}$ & 0 & $\mathbf{F}$ & 82 & 9 & 0 & 0 & 0 & 0 & .. & .. & .. & $\cdots$ \\
\hline $\begin{array}{r}\text { lus vulgaris } 5053 \\
P . \text { vulgaris } 5053 \times\end{array}$ & 0 & $\mathbf{F}$ & 40 & 0 & 0 & $\mathbf{0}$ & 0 & 0 & .. & .. & .. & ... \\
\hline $\begin{array}{c}\text { Pinto............. } \\
\text { Pinto } \times \text { Striped }\end{array}$ & 0 & $\mathbf{F}$ & 136 & 0 & 0 & $\mathbf{0}$ & 0 & 0 & $\mathbf{F}$ & 47 & 47 & $18-43$ \\
\hline $\begin{array}{l}\text { Hopi........... } \\
\text { Long Kidney } \times\end{array}$ & $\mathbf{0}$ & G & 103 & $\mathbf{0}$ & 0 & 0 & $\mathbf{0}$ & 0 & $\mathbf{F}$ & 48 & 48 & $19-56$ \\
\hline $\begin{array}{l}\text { Pinto } \ldots \ldots \ldots \ldots \\
\text { Pinto } \times \text { Pink }\end{array}$ & $\begin{array}{l}0 \\
0\end{array}$ & $\mathbf{F}$ & 96 & 0 & 0 & 0 & 0 & 0 & $\mathbf{F}$ & 38 & 38 & $18-44$ \\
\hline $\begin{array}{l}\text { Pinto } \times \text { Pink } . . . \\
\text { Pinto } \times \text { Pink. } .\end{array}$ & $\begin{array}{l}0 \\
0\end{array}$ & $\begin{array}{l}F \\
G\end{array}$ & $\begin{array}{l}43 \\
39\end{array}$ & $\begin{array}{l}21 \\
22\end{array}$ & $\begin{array}{l}6 \\
6\end{array}$ & $\begin{array}{l}5 \\
3\end{array}$ & 0 & $\begin{array}{l}0 \\
0\end{array}$ & G & 64 & $\ddot{64}$ & $10-128$ \\
\hline
\end{tabular}

* $\mathrm{F}=$ field-grown; $\mathrm{G}=$ greenhouse-grown.

viously discussed, have shown that these resistant varieties, Pinto, Lady Washington, Hungarian, Yellow, Long Kidney, Striped Hopi, Phaseolus vulgaris 5053, and Pink, contain one dominant factor for resistance. The fact that intercrossing of these varieties gave no segregating plants indicates that they all contain the same main factor for resistance. Additional $\mathrm{F}_{2}$ populations of all the crosses were grown in the field in order to obtain seed for $\mathrm{F}_{3}$ generations. The individual plants were examined for mildew, but none were found to be infected.

$\mathrm{F}_{3}$ generations of six of these crosses were grown in the field and one of these-Pinto $\times$ Pink-was also grown in the greenhouse. This one and also Phaseolus vulgaris $5053 \times$ Pinto and Long Kidney $\times$ Pinto were dish-tested; the results on the others were taken from field readings. The 
number of families found resistant and the range in the $\mathrm{F}_{3}$ populations are given in table 10. None of the plants from any of the crosses showed any susceptibility, all families appeared to be homozygous for resistance. Thus the result from the $\mathrm{F}_{2}$ is confirmed, namely, that the resistant varieties, Pinto, Lady Washington, Hungarian, Yellow, Phaseolus vulgaris 5053, Striped Hopi, Long Kidney, and Pink contain the same genetic factor for resistance.

\section{SUMMARY}

In determining the susceptibility of the $\mathrm{F}_{1}, \mathrm{~F}_{2}$, and $\mathrm{F}_{3}$ of crosses between resistant and susceptible varieties of beans (Phaseolus vulgaris L.) to powdery mildew (Erysiphe polygoni D. C.) (form 1), the mildew was grown in petri dishes on detached bean leaflets supported on cotton soaked in a 10 per cent sucrose solution as in earlier work. For certain $F_{3}$ generations, field inoculation was used. The susceptibility of individual plants was determined by inoculating detached leaflets or fragments of leaflets in petri dishes. Mildew readings were made on a scale of $0-4$; where field inoculation was used, readings indicated only whether the plants were susceptible or resistant.

The varieties Striped Hopi, Lady Washington, Hungarian, Yellow, Long Kidney, Phaseolus vulgaris 5053, and Pinto were found to be resistant in all stages of development, while Pink was susceptible in its youngest stages but resistant in older stages. The varieties Robust, Small White, Kotenashi, and Red Kidney were susceptible, while Long Roman was semiresistant in the field but susceptible in the dishes.

The $F_{1}$ and $F_{2}$ of Robust $(S) \times$ Striped Hopi $(R)$ and its reciprocal cross were tested by the dish method, and the $\mathrm{F}_{3}$ of the former was tested by field inoculation. The $\mathrm{F}_{2}$ segregated in a ratio of 3 resistant to 1 susceptible, both on the basis of the test of the individual $\mathrm{F}_{2}$ plants and their $\mathrm{F}_{3}$ progenies. This establishes the resistance to mildew to be due to a single dominant Mendelian factor pair.

Similar results were arrived at in crosses of Lady Washington $\times$ Small White, Long Roman $\times$ Lady Washington, Robust $\times$ Hungarian, Long Roman $\times$ Hungarian and its reciprocal cross, Yellow $\times$ Long Roman, Robust $\times$ Yellow, Phaseolus vulgaris $5053 \times$ Red Kidney, Long Kidney $\times$ Red Kidney, Robust $\times$ Pink, and Pink $\times$ Kotenashi.

In crosses between resistant varieties, $\mathrm{F}_{1}, \mathrm{~F}_{2}$, and $\mathrm{F}_{3}$ from Lady Washington $\times$ Pinto, Hungarian $\times$ Pinto, Yellow $\times$ Pinto, Phaseolus vulgaris $5053 \times$ Pinto, Pinto $\times$ Striped Hopi, Long Kidney $\times$ Pinto, Pinto $\times$ Pink, and $F_{1}$ and $F_{2}$ from Yellow $\times$ Hungarian and Yellow $\times P$. vulgaris 5053 were all resistant, which indicates that these resistant varieties carry the same single Mendelian factor for resistance to mildew. 